Spring 1994

\title{
LAW AND THE SHAPING OF THE AMERICAN LABOR MOVEMENT
}

Russell Hollander

Follow this and additional works at: https://digitalcommons.nyls.edu/journal_of_human_rights

Part of the Law Commons

\section{Recommended Citation}

Hollander, Russell (1994) "LAW AND THE SHAPING OF THE AMERICAN LABOR MOVEMENT," NYLS Journal of Human Rights: Vol. 11 : Iss. 2 , Article 7.

Available at: https://digitalcommons.nyls.edu/journal_of_human_rights/vol11/iss2/7

This Book Review is brought to you for free and open access by DigitalCommons@NYLS. It has been accepted for inclusion in NYLS Journal of Human Rights by an authorized editor of DigitalCommons@NYLS. 


\title{
BOOK REVIEW
}

\author{
A review of LAW AND THE SHAPING OF THE AMERICAN LABOR \\ MOVEMENT. \\ by William E. Forbath. \\ Cambridge, MA/London: \\ Harvard University Press (1991) \\ Pp. 211.
}

\section{Reviewed by Russell Hollander}

For decades, labor historians have sought to explain the "uniqueness" of the American Labor movement. "America's labor laws provide far fewer [statutory] protections against exploitation, injury, illness, and unemployment than the laws of the dozen other leading Western industrial nations. "1 Unlike employers in these other nations, an American employer can discharge a non-union employee for refusing to attend employer-sponsored prayer sessions, ${ }^{2}$ for being homosexual, ${ }^{3}$ or for refusing to drive uninspected trucks. ${ }^{4}$ Moreover,

- Copyright 1994 by the New York Law School Journal of Human Rights.

- Attorney, Cohen, Weiss \& Simon, New York, New York; Member, American Bar Association (Section on Labor \& Employees Law); Member, New York State Bar Association (Section of Labor Relations); Contributing Editor, The Railway Labor Act (forthcoming); Adjunct professor, State University of New York, College of Old Westbury (Labor Studies); J.D., cum laude, Harvard Law School, 1988; B.S., Cornell University, 1985.

${ }^{1}$ WILliam E. Forbath, LAW and the ShapING OF THE AMERICAN Labor MOVEMENT 1 (1991).

${ }^{2}$ See Kolodziej v. Smith, 588 N.E.2d 634 (Mass. 1992); Court Finds No First Amendment Violation in Mandatory Seminars with Religious Bent, DAILY LAB. REP., Apr. 8, 1992, at A-3 (reporting that mandatory seminars with religious overtones did not violate employees' First Amendment rights because the employer did not inhibit employees from practicing their religious faith). But see EEOC v. Townley Eng'g \& Mfg., 859 F.2d 610, 612 (9th Cir. 1988) (holding that requirement that employer accommodate employee's religion objections to devotional services by excusing him from attendance would cause no undue hardship).

${ }^{3}$ See Singer v. United States Civil Serv. Comm., 530 F.2d 247 (9th Cir. 1976), vacated, 429 U.S. 1034 (1977); Coretta King Endorses Gay Rights Bill, THE LEGAL INTELLIGENCER, June 24, 1994, at 6; Workplace Discrimination Bill Gets Support, THE Legal INTElligenCER, June 24, 1994, at 11; Civil Rights Chief Patrick Speaks His Mind, Legal Times, May 30, 1994, at 9. 
the few statutory protections that exist exclude a large percentage of the American labor force. For instance, the minimum wage and overtime provisions of the Fair Labor Standards Act exclude more than twenty-five percent of the American work force, ${ }^{5}$ the unemployment insurance laws exclude approximately twenty-five percent of the American labor force, ${ }^{6}$ and twenty percent of the labor force is excluded from worker's compensation laws. ${ }^{7}$ Rather than turning toward inclusive social legislation, American workers have traditionally formed trade unions and negotiated collectively with their employers for the majority of their employment-related protections. ${ }^{8}$ In the United States, collective bargaining agreements, and not legislation, provide workers with primary protection against arbitrary dismissal, sickness, and inadequate retirement income.

The traditional, or classic, labor historians have argued that the "uniqueness" of the American Labor movement derives from the "uniqueness" of the American worker. ${ }^{9}$ According to the traditionalists, American workers are a conservative lot that have spurned broad visions of social reform in favor of individualistic strategies for improving their fortunes. ${ }^{10}$ Professor Derek C. Bok

4 See, e.g., NLRB v. City Disposal Sys., 465 U.S. 822 (1984).

529 U.S.C. \& 201 (1988); see Peter D. DeChiara, Rethinking the ManagerialProfessional Exemption of the Fair Labor Standards Act, 43 AM. U. L. REv. 139 (1993) (arguing that the Fair Labor Standards Act should include managerial and professional employees in order to reduce white-collar unemployment and the amount of overworked employees).

${ }^{6}$ See 29 U.S.C. \& 151 (1988); Derek C. Bok, Reflections on the Distinctive Character of American Labor Laws, 84 HARV. L. REV. 1394, 1418 (1971) (discussing the more active role of European governments in legislation and benefit provisions, as well as the large disparity between retirement benefits of European and American workers).

${ }^{7}$ Bok, supra note 6, at 1418 .

${ }^{8}$ See id. at 1419 (asserting that historically, American unions have represented the interests of their members rather that the interests of workers as a class).

${ }^{9}$ Forbath, supra note 1 , at 10; see JOHN COMMONS, ET AL., 2 HISTORY OF LABOUR IN THE UNITED STATES 218-22 (1953) (tracing the influence of the European International on European Labor movement).

${ }^{10}$ See Bok, supra note 6, at 1439 (contending that American workers join unions to achieve better wages and working conditions); see also id. at 1402 (suggesting that a lack of cohesion is reflected by "general reluctance to engage in many other forms of mutual endeavor"); see, e.g., Selig PERLman, A THEORY of THE Labor Movement (1923), reprinted in 2 HISTORY OF LABOUR IN THE UNITED STATES 206-07 (John 
contends that "the patterns of behavior and the institutions that make up our system of industrial relations have had a more fundamental influence than any other factor" in shaping substantive American labor law. ${ }^{11}$ According to Professor Bok, workers in the United States have avoided class-based social reform due to: (1) "marked reluctance to subordinate their individual autonomy to the control of larger organizations; "12 (2) the characteristic of American workers to be less prone to identify themselves as members of a class and less inclined to join together to achieve common objectives $;{ }^{13}$ and (3) a lack of cohesion based upon a "network of language, racial and religious barriers . . . often lead[ing] to factions within the ranks of Labor . . . [and giving] rise to various forms of discrimination, especially against [African-Americans] and immigrants who often . .. served as strikebreakers. "14

Professor William E. Forbath ${ }^{15}$ of the U.C.L.A. School of Law has adopted a fascinating and compelling alternative explanation of the "uniqueness" of the American Labor movement. In his book, entitled Law and the Shaping of the American Labor Movement, Forbath argues that legal doctrine and judicial decisions constitute the primary, if not exclusive, factors in the shaping of the American Labor movement. ${ }^{16}$ According to Forbath, American workers, like their European counterparts, initially sought to curb unbridled capitalism through a host of legislative reforms such as "hours laws

Commons ed., 1953) (contrasting American and European ideas, stating that "the [International] advocated economic organisation prior to and underlying political organisation, while [Lasalle] considered a political victory as the basis of Economic Organisation").

${ }^{11}$ Bok, supra note 6 , at 1400 (arguing that causation may be traced to the very foundation of American society and its complicated chain of human affairs).

${ }^{12}$ Id. (citing detailed discussion in PHILIP E. SLATER, ThE PURSUIT OF LoNeliness: AMERICAN CULTURE AT THE BREAKING POINT 7-9 (1970)).

${ }^{13}$ Id. at 1401 (explaining lack of "solidarity" among American workers).

${ }^{14} \mathrm{Id}$. at 1403. According to Professor Bok, a lack of cohesion makes it impossible for American workers to "achieve the degree of unity reached in certain Western European countries." Id.

15 Professor, University of California at Los Angeles; Ph.D., Yale University, 1992; Instructor of American Studies, Yale University, 1984-89; J.D., Yale Law School, 1983; Golieb Fellow in Legal History, New York University, 1982-83; Clerk, Judge Louis H. Pollack, 1981-82; Co-Author, The NIXON YeARS, 1976.

${ }^{16}$ ForBath, supra note 1 , at 3. 


\section{NYLS JOURNAL OF HUMAN RIGHTS [Vol. XI}

and other work-place regulations, the abolition of private banking, public funding for worker-owned industry, and the nationalization of monopolies. ${ }^{17}$ Only after the judiciary declared such legislative reform efforts unconstitutional ${ }^{18}$ did Labor adopt collective bargaining as its primary weapon against the rigors of industrialized society. ${ }^{19}$ Forbath asserts:

During the decades bracketing the turn of the century, courts exacted from labor many key strategic and ideological accommodations, changing trade unionists' views of what was possible and desirable in politics and industry. Judicial review and administration of labor legislation helped make broad legal reforms seem futile. Similarly, the courts' harshly repressive law of industrial conflict helped make broad, inclusive unionism seem too costly and a more cautious, narrower unionism essential.

Courts shaped labor's strategic calculus; . . . . [T]he proliferation of anti-strike and anti-boycott decrees riveted trade unionists' political energies on repealing this judge-made regime. . . . [T]he burdens and indignities of semi-outlawry made challenging judgemade labor law a constant endeavor in the courts, in legislatures, and in the public sphere. At the same time, the courts' very sway made common law and constitutional discourse beckon as the surest framework within which to contend for legitimacy and relief. Thus, labor leaders at all levels began to speak and think more and more in the language of the law

\footnotetext{
${ }^{17}$ Id. at 13 (citing William E. Forbath, Ambiguities of Free Labor: Labor and Law in the Gilded Age, 1985 WIS. L. REv. 767, 807-09 (1985)).

${ }^{18}$ See, e.g., Lochner v. New York, 198 U.S. 45, 57-65 (1905) (holding that under the Constitution, freedom of contract prevails over the power of the state to legislate).

${ }^{19}$ See PAUl Kens, Judicial POWER AND REForm POLITICS: THE ANATOMY OF LOCHNER V. NEW YORK 129-30 (1990) (explaining that organized labor did not like the Lochner decision, but instead of pursuing their goals through legislation, preferred collective bargaining and thought that if an organization was strong enough, it could enforce its own goals without the help of the law).
} 
. . . . [L]abor's embrace of a law-inspired, laissezfaire rights talk displaced a more radical vocabulary of reform. In this fashion,... . the legal order encouraged a reshaping of the labor movement's dominant ideology. ${ }^{20}$

Forbath's book presents a thought-provoking alternative explanation of the distinctiveness of American labor law. The book is essential reading for labor scholars. However, Forbath's book is not without its faults. Although contending not to judge Labor's decision to seek protection through collective bargaining rather than legislation, ${ }^{21}$ Forbath unquestionably implies that Labor must abandon its emphasis on contractual protections and must instead seek comprehensive and inclusive legislative reform. As explained in Part II of this review, it is here that I disagree with Forbath.

\section{The Book}

Forbath's analysis begins with a critical examination of the voluntarist perspective, which was first drawn by the founders of American labor history. ${ }^{22}$ According to the author, "the new labor historians have undermined the traditional assumption that American workers were more individualistic and less disposed than their English or European counterparts" to engage in broad-based political action. ${ }^{23}$ Drawing upon recent historical research, Forbath asserts that actually "most Gilded Age trade unionists were steeped in labor politics and reform, and most reformers were active trade unionists. "24 Supporting his assertion, Forbath describes the activities

\footnotetext{
${ }^{20}$ FORBATH, supra note 1 , at 6-8.

${ }^{21}$ See id. at 172 (stating that policy prescriptions, however, are not the author's stock in trade).

${ }^{22} \mathrm{Id}$. at $10 \mathrm{n} .1$. John Commons, Selig Perlman, and German sociologist, Werner Sombart, are designated as the founders of American labor history. Id.

${ }^{23} \mathrm{Id}$. at 11.

${ }^{24} \mathrm{Id}$. at 12 (footnote omitted). The Gilded Age was a "period of currency inflation, wide-spread speculation, overexpansion of industry, loud booming of dubious enterprises, loose business and political morals, and flashy manners that extended from the end of the Civil War in 1865 to the Panic of 1873." 3 Dictionary OF AMERICAN
} 
of the Knights of Labor, the Gilded Age's largest and most powerful labor organization, ${ }^{25}$ which "created labor parties, ran candidates in thirty-four of the country's thirty-five states, [and] elected members to city and state governments. They founded factory cooperatives and established a panoply of cultural associations. "26 The Knights' professed goal was to prepare the working class for republican selfrule. ${ }^{27}$ According to Forbath:

The Knights hewed to a working-class version of traditional republican ideas about law and rights. They held that republican government rested on a virtuous and independent citizenry; and that citizens' political and economic independence were intertwined, both requiring a rough measure of economic equality. ... [T] [They saw as law's chief aim not the security of private rights but the preservation of the social conditions necessary for such a self-governing citizenry. Workers read these traditional principles to mean that in an industrial society the very survival of republican government demanded the use of governmental power to quell the "tyranny" of corporations and capital. ${ }^{28}$

Forbath further asserts that the more conservative American Federation of Labor (AFL) initially shared the Knights' radical reform ambitions. ${ }^{29}$ In 1894, "a majority of the AFL's constituent unions endorsed a socialist platform that called for 'independent labor

HISTORY 180 (1976).

${ }^{25}$ FORBATH, supra note 1, at 12.; see SAMUEL GOMPERS, SEVENTY YEARS OF LIFE AND LABOR: AN AUTOBIOGRAPHY xix (Nick Salvatore ed., 1984) (describing the founding of the Knights of Labor).

${ }^{26}$ FORBATH, supra note 1 , at 13; see LEON FINK, WORKINGMEN's DEMOCRACY: THE KNIGHTS OF LABOR AND AMERICAN POLITICS 8-9 (1983) (describing the value of culture in the advancement of democratic civilization).

${ }^{27}$ FORBATH, supra note 1 , at 13.

${ }^{28} \mathrm{Id}$. at 13 (footnote omitted); see FINK, supra note 26, at 14 (describing the Knights as forming the backbone of local labor movements and as "first of all a coalition of reactivating, or already organized, trade unions") (footnote omitted).

${ }^{29}$ FORBATH, supra note 1 , at 14. 
politics' and an eleven point legislative program" calling for workplace regulation, a universal eight-hour day and national ownership of industry. ${ }^{30}$

Similarly, Forbath rejects the traditionalists' claim that ethnic and racial divisions prevented the creation of "broad class-based organizational solidarities, ${ }^{131}$ yet concedes that ethnic divisions often impeded the creation of class-based alliances. ${ }^{32}$ Forbath argues "that, by themselves, these divisions hardly account for the sharp narrowing of American labor politics. "33 To support this conclusion, Forbath notes that "the Knights reached out from a base among coal miners and artisans to a constituency that embraced the burgeoning new factory proletariat-and included new immigrants, blacks, and women alongside old immigrants and old stock Americans . . . ."134 As further support, Forbath relates the merging of native-born skilled railway workers with the railroads' new immigrant semi-skilled and unskilled workers by enlistment in the Knights of Labor railway branches, as well as, in locals of Eugene Debs' American Railway Union. ${ }^{35}$ Forbath denies ethnic antagonism as a factor leading to the demise of these labor organizations, ${ }^{36}$ concluding that the explanation

${ }^{30} I d$. at 14 (citing Martin Shefter, Trade Unions and Political Machines: The Organization and Disorganization of the American Working Class in the Late-Nineteenth Century, in Working-Class Formation: Nineteenth-Century Patterns IN WESTERN EUROPE AND THE UNTTED STATES 257 (Ira Katznelson \& Aristide R. Zolberg eds., 1986) [hereinafter WORKING-CLASS FORMATION] (acknowledging that the ultimate rejection of the socialist platform at the 1894 AFL Convention was due to "parliamentary sleight-of-hand" by the AFL leadership)).

${ }^{31} \mathrm{Id}$. at 23.

32 Id. at 24.

33 Id. (footnote omitted).

${ }^{34}$ FORBATH, supra note 1, at 13 (citing FINK, supra note 26, at 169) ("The Knights loomed in the mid-1880's as a beacon of racial enlightenment"); see id. at 221 (emphasizing the critical dependence of the Knights of Labor upon worker cooperation across diverse racial and ethnic communities).

${ }^{35}$ Id. at 23 (citing FINK, supra note 26, at 169).

${ }^{36}$ See FoRBATH, supra note 1, at 35; see, e.g., FNK, supra note 26, at 219 (describing union organization as a result of common experiences and shared economic antagonisms). 


\section{NYLS JOURNAL OF HUMAN RIGHTS [Vol. XI}

for a social movement devoid of class distinctions must lie elsewhere. ${ }^{37}$

Thus, having dispelled the traditionalists' explanation of the American Labor movement's "uniqueness," Forbath presents a forceful story of how the courts and legal dogma forever altered the American Labor movement. ${ }^{38}$ Drawing upon extensive legal and historical research, ${ }^{39}$ he argues that the Gilded Age activists suffered such severe setbacks from the courts ${ }^{40}$ that they abandoned their early efforts to establish class-based legislative reform. ${ }^{41}$ The activists, instead, adopted the narrow self-interested philosophy of "voluntarism" that now permeates the American Labor movement. ${ }^{42}$ According to Forbath, the transformation of the American Labor movement from a radical class-based movement to one based upon

${ }^{37}$ See FORBATH, supra note 1 , at 25 (supporting the conclusion that ethnic antagonism does not account for the distinctive character of the American Labor movement, contrasting the ethnicity of the American Labor movement with that of Europe, and noting that European countries shared similar ethnic conflicts); see also FINK, supra note 26, at 221 (offering the "splintering off of the skilled membership when the Knights no longer met their needs," as a reason for the demise of the Knights of Labor and assigning the economic and political success of the Knights in the biracial South to "the cooperation of disaffected white Democrats with black Republicans"); Aristide R. Zolberg, How Many Exceptionalisms?, in WORKINO-Class FORMATION, supra note 30, at 425-30 (noting the commitment of working class organizations to the pursuit of their objectives even if they included revolutionary change).

${ }^{38}$ FORBATH, supra note 1 , at $25-33$

${ }^{39}$ Id.

${ }^{40} 1 d$. at 27-28 (describing the courts' role in protecting and nurturing the economy and society).

${ }^{41} \mathrm{ld}$. at 2 .

${ }^{42}$ Id. at 1-2 n.3 (quoting Samuel Gompers, Judicial Vindication of Labor's Claims, 7 AM. FEDERATIONIST 283, 287 (1901) (defining voluntarism as a labor historian's term for [L]abor's "staunch commitment to the 'private' ordering of industrial relations between unions and employers"). "Voluntarism teaches that workers should pursue improvements in their living and working conditions through collective bargaining and concerted action in the private sphere rather than through public political action and legislation." Id. at 1-2. Voluntarism can also be referred to as "[L]abor's version of laissez-faire, and statist philosophy that says the "best thing the State can do for labor is to leave labor alone." Id; see GOMPERS, supra note 25, at xxiv-xxv (describing the alteration of voluntarism, evolving from a denial of a state role in industrial relations to a belief in individualism which "threatened the justification of any group organization" in its exclusion of a "complex political economy" that governed American industrialization). 
voluntarism occurred in three stages. ${ }^{43}$

\section{A. The First Transformation}

First, the courts nullified Labor's early attempts at broadbased inclusive legislative reform. ${ }^{44}$ Labor's primary goals during the late-nineteenth century were to legislate a shorter workday, to curtail "sweat shops" through legislative bans on manufacturing in tenement dwellings, to abolish payment of wages by company scrip, and to prohibit anti-union discrimination. ${ }^{45}$ However, Labor's early successes in enacting such protective legislation proved unavailing. ${ }^{46}$ Once passed, the judiciary sharply disemboweled or invalidated Labor's legislative victories. ${ }^{47}$ "By the turn of the century state and federal courts had invalidated roughly sixty labor laws. "48 Foremost among these decisions was the Supreme Court's Lochner v. New York $^{49}$ decision and the New York Court of Appeals' In re Jacobs ${ }^{50}$

${ }^{43}$ ForBath, supra note 1 , at 25 . The three central features molding 19 th century labor politics are denominated by Forbath as "federalism, the nature and role of political parties, and the absence of an administrative state elite (or, what is the other side of the same coin, the judiciary's role as the era's sole state elite)." Id.

44 See id. at 38 (citing the legislation that was overturned and invalidated nationwide between 1885 and 1930 by state and federal courts including the United States Supreme Court; the legislation struck down involved such matters as discrimination against union members, weighing of coal at mines, regular payment of wages, payment by scrip, hours, child labor, blacklisting, employment of women, etc.).

${ }^{45}$ Id. at 37; see Shefter, in WORKING-Class FORMATION, supra note 30, at 263 (designating "[L]abor's pursuit of the eight-hour day" as the driving force behind the changes in the American Labor movement's orientation to politics, and modes of action and organization); see also GOMPERS, supra note 25, at 94 (discussing the 1868 eighthour law for federal employees, which was virtually ignored; the response to enforcement of this law resulted in the interpretation that "a reduction in wages must accompany a reduction in hours").

${ }^{46}$ FORBATH, supra note 1 , at 38 .

${ }^{47} \mathrm{Id}$.

${ }^{48}$ Id. (citing numerous cases which held that strikes to enforce union work standards and work rules were illegal); see, e.g., Benito Rovira Co. v. Yampolsky, 187 N.Y.S 894 (Sup. Ct. 1921); Hopkins v. Oxley Stave Co., 83 F. 912 (8th Cir. 1897); Folsom Engraving Co. v. McNeil, 126 N.E. 479 (Mass. 1920).

49198 U.S. 45 (1905).

so 98 N.Y. 98 (1885). 
decision. In both cases, the judiciary found that laws designed to protect employees from undue exploitation violated the Fourteenth Amendment because the laws interfered with the constitutional right of employee and employer to enter into contracts free from state interference. ${ }^{51}$

In Lochner, the Supreme Court invalidated a New York law forbidding employment in a bakery for more than sixty hours a week or ten hours a day. ${ }^{52}$ Emphasizing the Court's growing intolerance with "interference" by state legislatures in the free market economy, the Court declared that "the freedom of master and employe to contract with each other in relation to their employment, and in defining the same, cannot be prohibited or interfered with, without violating the Federal Constitution." 53 In Jacobs, New York State's highest court struck down legislation that would have banned the manufacturing of cigars in tenement dwellings. ${ }^{54}$ As with Lochner, the Jacobs court emphasized the judiciary's disdain for legislation that interfered with "free labor." 55

Forbath contends that the effect that these decisions had upon the ideology of the American Labor movement is far more important than the courts' actual holdings. ${ }^{56}$ Prior to Jacobs, Samuel Gompers maintained "strong ties to the Marxist branch of the first International, "57 and, although he opposed "Lassallean" socialism, ${ }^{58}$ "he remained open to political radicalism." 59 Indeed, Gompers led

${ }^{51}$ Lochner, 198 U.S. at 64; Jacobs, 98 N.Y. at 115.

52198 U.S. at 58.

${ }^{53} I d$. at 64.

5498 N.Y. at 115 (applying constitutional protections of "personal liberty and private property" to strike down a New York City public health law).

ss Id. at 106-07 (upholding "right to choice of a trade or profession" as a fundamental right of liberty under the Constitution).

${ }^{56}$ Id. at 42 (citing GOMPERS, supra note 25, at 196).

${ }^{57}$ FORBATH, supra note 1, at 40; see GoMPERS, supra note 25 , at 60 (describing socialist influence on "the old International").

${ }^{58}$ FORBATH, supra note 1 , at 40 (stating that Lasallean socialism discouraged involvement in trade unions in "favor of political engagement").

${ }^{59} \mathrm{Id}$. at 40. Contra GoMPERs, supra note 25 , at 65-66 (specifying that the Economic and Sociological Club, a group of trade unionists formed for the purpose of extending and defending principles of trade unionism, "refused to subordinate the trade union to any 'ism' or political 'reform'"). 
the cigar-makers' efforts to secure the protective legislation ${ }^{60}$ that was later invalidated in Jacobs. ${ }^{61}$ According to Forbath, the Jacobs decision discouraged Gompers' efforts in the political arena. ${ }^{62}$ Gompers soon learned that, in an age of judicial supremacy, ${ }^{63}$ "[s]ecuring the enactment of a law does not mean the solution of the problem . . . . [T]he power of the courts to pass upon constitutionality of law so complicate[s] reform by legislation as to seriously restrict the effectiveness of that method. ${ }^{\text {"64 }}$

Forbath's first transformation was now complete. Subsequent to the dismantling of Labor's protective legislation, the American Labor movement and, in particular, the AFL abandoned broad-based political reforms in favor of a comprehensive plan of class-based economic warfare. ${ }^{65}$ Forbath explains that the "[i]nvalidated labor laws were powerful evidence of and a metaphor for the recalcitrance of the American state and the wisdom of voluntarism . . . . [T]he American workplace seemed, increasingly, the only worthwhile avenue for gaining reforms . . . ."66

\section{B. The Second Transformation}

When Labor turned from political reform to economic action,

${ }^{60}$ GOMPERS, supra note 25 , at 58 . The great strike was described as ending in a compromise that created "a sense of power that struggle develops." Id.

6198 N.Y. at 115; see FORBATH, supra note 1, at 39-41; see also GOMPERS, supra note 25, at 61-62 (characterizing legislative enactments followed by judicial invalidations as fuel for the accomplishment of union goals through means other than legislation).

${ }^{62}$ ForBATH, supra note 1, at 41-42. But see GoMPERs, supra note 25, at 66. Gompers' membership in the Economic and Sociological club brought about his realization that "the trade union was the fundamental agency through which we could achieve economic power, which would in turn give us social and political power." Id. Further, according to Gompers, partisanship was refused not only because its methods were essentially different from those of industry but also because "legislation could affect the lives of men at work in a very few points-and those not vitally important for progressively improving conditions." Id.

${ }^{63}$ FoRBATH, supra note 1 , at 41.

64 See GOMPERS, supra note 25, at 194.

${ }^{65}$ See FORBATH, supra note 1, at 54-57.

${ }^{6}$ Id. at 54-55. 
the courts extended the labor injunction ${ }^{67}$ to halt all but the most "minimalist" economic action. ${ }^{68}$ Unlike today's labor disputes, latenineteenth and early-twentieth century labor disputes consisted of class-based economic boycotts coupled with extensive secondary strike activity. ${ }^{69}$ As Forbath explains:

The boycott's aim and the solidarities it established beyond individual work-places distinguished this weapon from the typical strike ... . [T] The 1880's boycott was almost always a rich illustration of what treatise writers would soon be calling a "compound" or "secondary" boycott. If a city labor federation, for example, called a boycott against a brewer . . . it would do more than proclaim his beer "unfair." Representatives would visit saloons and call on them to cease serving his beer or face boycotts and picket lines themselves. Similarly, a boycott against a printer meant notifying all the printer's customers-"hotels, boarding houses, public schools, railroads and steamships" - that all who continued to patronize the printer would be put on the city labor weekly's "black list. "70

The courts had no patience for Labor's attempts to turn socalled "individual" labor disputes into broad class-based struggles. ${ }^{71}$ "The[] boycotts provoked [the] courts' anxiety and rage, in part because they mobilized whole working-class populations . . . .72 "Declar[ing] tha[t] an entrepreneur's or worker's right to pursue his

${ }^{67}$ Id. at $84-85$. Generally, the courts view boycotts as an assault on the courts and state, as well as, on marketplace freedom. Id.

${ }^{6}$ See id. (explaining how minimalist economic actions became non-existent when equity judges held employer's profit-making activity to be part of his "property;" all boycotts, therefore, became unlawful).

${ }^{69}$ Id. at 82-83; see Shefter, in WORKING-Class FORMATION, supra note 30, at 22021 (characterizing boycotts as a secondary form of collective action).

${ }^{70}$ FoRBATH, supra note 1 , at 82-83 (footnotes omitted).

${ }^{71}$ See id. at 83 (explaining how entire working class populations, families, and communities were mobilized to support boycotts).

${ }^{n}$ Id. 
calling or business was a constitutional property right, "73 the courts acted swiftly and delineated a "realm of legitimate strikes. "74 "The general rule was that strikes seeking no gain for the strikers . : . were deemed to be prompted by malice, "75 which caused many union strikes to be categorized as illegal. ${ }^{76}$

In the $1890 \mathrm{~s}$, for instance, "courts enjoined at least 15 percent of recorded sympathy strikes. That percentage rose to 25 percent in the next decade, and by the 1920s[,] 46 percent of all sympathy strikes were greeted by anti-strike decrees." 77 Forbath asserts that "[i]njunctions figured in virtually every railroad strike; in most strikes in which industrial unionism, 'amalgamation,' or 'federation' was at issue; in most major organizing and recognition strikes, boycotts, closed shop or sympathy strikes . . . ."78

Moreover, when Labor resisted the court's broad injunctions, the federal courts "ordered local officials . . . to refrain from enforcing the criminal law against strikebreakers and company police." 79 If the local authorities resisted, the federal courts would deputize private police or encourage state and federal troops to intervene in the dispute on behalf of the employer. ${ }^{80}$ Faced with broad injunctions, contempt citations, and jail, ${ }^{81}$ Labor decided to

${ }^{73} \mathrm{Id}$. at 87.

${ }^{74} \mathrm{Id}$. at 88-89.

${ }^{75}$ FORBATH, supra note 1 , at 89.

${ }^{76} \mathrm{Id}$. (citing cases which held that strikes to enforce union work standards and work rules were illegal); see, e.g., Folsom Engraving Co. v. McNeil, 126 N.E. 479 (Mass. 1920) (awarding injunctive relief against worker picketing and upholding right of employer to hire workmen, unhampered by union interference); Benito Rovira Co. v. Yampolsky, 187 N.Y.S. 894 (Sup. Ct. 1921) (granting injunction to prevent picketing in front of plaintiff's place of business); Hopkins v. Oxley Stave Co., 83 F. 912 (8th Cir. 1897) (upholding grant of temporary injunction and acknowledging the right to form labor organizations yet condemning interference, "other than by lawful competition, with the business affairs of others").

${ }^{7}$ FORBATH, supra note 1, at 62.

${ }^{78} I d$. at 62 (footnote omitted).

79 James G. Pope, The Past of Labor Law-and its Future, 39 UCLA L. ReV. 481, 486 (1992) (citing FoRBATH, supra note 1, at 103-04).

${ }^{80} \mathrm{ld}$. at 486.

${ }^{81}$ FORBATH, supra note 1 , at 74-75. 


\section{NYLS JOURNAL OF HUMAN RIGHTS [Vol. XI}

moderate its economic campaign. ${ }^{82}$

By the early 1890 s, the courts had thus convinced most Labor leaders that "broad, inclusive strikes would run up against violent state opposition, and that state force would arrive with high legal sanctions. "83

Forbath's second transformation was complete. Aware that "broad class-based" economic actions "were too costly and selfdefeating, "84 the American Labor movement decided "to conserve and build upon what 'worked'-minimalists politics, craft unionism, high dues, and restrained but well-calculated strike policies. "85

\section{The Third Transformation}

In the third and final transformation, Forbath contends that Labor's struggle for legitimacy eventually led Labor to immerse itself in the language of the law. ${ }^{86}$ In the end, Forbath asserts that law not only shaped the economic/political strategies employed by Labor, but it also transformed the American Labor movement's vision, identity and mission. ${ }^{87}$ According to Forbath:

[T]he law's social and political authority compelled speaking in the law's terms. Labor, moreover, was drawn to mining the fine radical veins of legal tradition. The result was a subtle but pervasive change in the labor movement's dominant language of protest and consciousness of rights. Legal discourse helped shape new principles and new parameters of argument; it infused new meanings into inherited

\footnotetext{
${ }^{82}$ See id. at 90-91, 95 (discussing the "less 'disorderly' form of boycotting" by informing public through labor newspapers about "unfair" products).

${ }^{83} \mathrm{Id}$. at 94.

84 Id. at 78 (footnote omitted).

${ }^{85}$ Id. at 96 (footnote omitted); see ChrisTOPHER L. TOMLINS, THE STATE AND THE UNIONS: LABOR RELATIONS, LAW, AND THE ORGANIZED LABOR MOVEMENT IN AMERICA 1880-1960 60-61 (1985) (describing the overwhelming defeat for unions and the goal of organized labor to seek accommodation within political economy).

${ }^{86}$ FORBATH, supra note 1, at 128.

${ }^{87}$ See id.
} 
ideals like "equal rights." Trade unionists also came to defend, and even to understand, specific outlawed union activities using new arguments, analogies, and metaphors inspired by the common law. ${ }^{88}$

Forbath argues that the labor activists of the 1880 s and 1890 s "embraced the radical ideas that wage labor was inconsistent with republican citizenship, that property was tyranny, and that government should intervene to impose republican principles on property and industry. "89 After being battered and beaten for two decades in the courts, Labor "abandoned [its] radical republican claims upon the government," ${ }^{90}$ and in the early-1900s adopted the "anti-statist liberalism that . . . resembled the philosophy of their judicial adversaries." 91 Instead of seeking the repeal of judge-made "contract" and "property" rights, Labor simply sought the extension of the same rights to labor. ${ }^{92}$ In attacking anti-boycott decrees, for instance, the AFL argued that "had the action taken by the labor organization instead been taken by manufacturers, it 'might have been fairly considered a legitimate battle of trade with which a court of equity should not have interfered.'" 93 The total transformation was now complete. Instead of attacking "property" and "contract" law, trade "unionists analogized labor rights to corporate property rights and lambasted the labor injunction as special government solicitude for [C]apital.".94

Forbath readily acknowledges that Labor's transformation from a radical "anti-capitalist" movement to a "distinctively" American Labor movement did not go unrewarded. ${ }^{95}$ The AFL's

${ }^{88}$ Id.

${ }^{89}$ Pope, supra note 79 , at 487 (citing ForBATH, supra note 1, at 129-30).

${ }^{90}$ FORBATH, supra note 1 , at 130 .

${ }^{91}$ Id.

${ }^{2}$ Id. at 134 . "Liberty of contract" is pinpointed as a sure way to legitimate collective action. $1 d$.

${ }^{93} 1 d$. at 132 (footnote omitted).

${ }^{94}$ Pope, supra note 79, at 487 (citing ForBaTH, supra note 1, at 131-32).

${ }^{95}$ ForBatH, supra note 1, at 148 (citing Labor Secures Test Vote, ILL. ST. FED'N LAB. WKLY. NEWSL., Apr. 4, 1925, at 1 (describing the outrage of Congress and state legislatures when "government by injunction" undermined trial by jury and trampled the First Amendment)). 


\section{NYLS JOURNAL OF HUMAN RIGHTS [Vol. XI}

adoption of "free market" ideologies ${ }^{96}$ allowed Labor to argue that (1) collective bargaining agreements should be entitled to the same protection afforded master/employee contracts; and (2) labor associations should be treated the same as any other "business" association. ${ }^{97}$ Building on the common law of capitalism and the United States Constitution, Labor argued that:

[O]rganized workers were freely associating citizens who ought to enjoy the same freedom of action and expression that individual workers and citizens enjoyed. To grant them such freedoms was to grant them no more than what "combinations of capital" enjoyed as legal persons. ${ }^{98}$

Labor's argument quickly won support from a number of influential judges, ${ }^{99}$ including Justice Holmes, ${ }^{100}$ and, ironically, Labor began obtaining injunctions prohibiting employers from conspiring to violate or induce violations of collective bargaining agreements. ${ }^{101}$ Labor obtained court orders upholding union strikes to enforce closed shop agreements. For example, in National Protective Association of Steam Fitters \& Helpers v. Cumming, ${ }^{102}$ the court upheld the Steam Fitters' right to strike for a closed shop on the grounds that union action was lawful because the action was within the "every-day acts of the business world," ${ }^{103}$ and apparently within the domain of competition as "judged according to the motive of the actor. ... . [These] principles concede the right of an association to

${ }^{96}$ See id. at 135-36 (describing legitimized "workers' collective action" as presumptively worthy of same treatment accorded employer's collective action).

${ }^{97} \mathrm{Id}$.

${ }^{98}$ Id. at 147 (footnote omitted).

${ }^{99}$ Id.

100 See Vegelahn v. Gunter, 44 N.E. 1077 (Mass. 1896) (Holmes, J., dissenting).

${ }^{101}$ FORBATH, supra note 1, at 124-25; see, e.g., Schlessinger v. Quinto, 192 N.Y.S. 564,569 (Sup. Ct. 1922), aff'd, 194 N.Y.S. 401,409 (App. Div. 1922) (upholding right of an employee organization to restrain their employer's violation of contractual obligations).

10263 N.E. 369 (N.Y. 1902).

${ }^{103} \mathrm{Id}$. at 371 (defining scope of lawful and unlawful organizational activities). 
strike in order to benefit its members. " 104

Additionally, Labor's adoption of a laissez-faire, free-market ideology ${ }^{105}$ allowed Labor to contend for "legitimacy" while actively defying the law. ${ }^{106}$ From the 1900s through the 1920s, Labor adopted a "campaign of massive and articulate defiance" of federal injunctions. ${ }^{107}$ When charged with lawbreaking, "[Labor] invoked [its] alternative constitutional vision. ${ }^{108}$ Over time, "many middle class 'experts' and reformers, many elite lawyers, academics, and politicians" 109 began to echo Labor's claim that government by injunction was unconstitutional. ${ }^{110}$ Eventually, Congress passed the Norris-LaGuardia Act, ${ }^{111}$ which banned most labor injunctions, and the National Labor Relations Act, ${ }^{112}$ which guaranteed employees the right to join and form labor unions. ${ }^{113}$

Although acknowledging Labor's victories, Forbath argues that the cost was too high. ${ }^{114}$ According to Forbath, Labor's adoption of the "dominant legal language" ratified American corporate power over economic life and, effectively, foreclosed "more radical ways of describing and criticizing the nation's political economy. "115

${ }^{104}$ Id. at 371-72.

${ }^{105}$ FORBATH, supra note 1, at 135.

${ }^{106} \mathrm{Id}$. at 145-47. The workers' perspective emphasized that judicial decisions were in violation of the Constitution. Id.

${ }^{107}$ Id. at 142.

108 Pope, supra note 79, at 489 (citing FORBATH, supra note 1, at 145-47 (explaining Labor's anaogly of defiance of "unjust laws" to an anti-slavery movement)).

109 Forbath, supra note 1, at 159.

${ }^{110}$ See id. at 159 (supporting claims that injunctions were to blame for industrial unrest); see also Pope, supra note 79, at 489 (explaining that middle class experts and legislators became aware that the worker support necessary for industrial stability was missing).

11129 U.S.C. $\S 101$ (1988) (originally enacted as Act of March 23, 1932, ch. 90, $\S 1,47$ Stat. 70 ).

11229 U.S.C. $\S \S 151-58,159-69$ (1988).

${ }^{113}$ See FORBATH, supra note 1, at 158-62 (following development of anti-injunction bill into the Norris-LaGuardia Act).

${ }^{114}$ Id. at 3. Forbath claims that Labor's broad vision of reform was dethroned by the rise of Samuel Gompers' "pure and simple" trade unionism. Id.; see GoMPERS, supra note 25 , at 385 .

${ }^{115}$ FORBATH, supra note 1, at 135. 


\section{Critique}

Forbath's Law and the Shaping of the American Labor Movement constitutes an important addition to the historian's debate regarding the distinction between the American Labor movement and the European Labor movement. Where other labor historians have focused upon the alleged "uniqueness" of the American worker and the American industrial system, ${ }^{116}$ Forbath focuses upon the American legal structure. ${ }^{117}$ Further, where other labor historians have viewed the law and the courts as playing a derivative role, ${ }^{118}$ Forbath asserts that the courts and legal doctrine constituted a primary motivating factor. ${ }^{119}$ "Although deeply indebted to the pioneers of American labor history . . . this book suggests that some of their key common assumptions about law's role in that history are wrong. "120 Albeit persuasive, Forbath's arguments are not without their flaws.

As an initial matter, Forbath's portrayal of the Gilded Age Labor movement is skewed. As some critics have noted: ${ }^{121}$

Forbath presents an inflated picture of [L]abor's radical potential. In [his] haste to correct the errors of previous labor historians [he] has committed the opposite error .... Forbath fails to confront the fact that the Noble and Holy Order of the Knights of Labor, which purportedly exemplified Gilded _..Age labor radicalism, had an official national policy prohibiting local assemblies from going so far as to

${ }^{116}$ See Bok, supra note 6, at 1458-59; SELIG PERLMAN, A THEORY OF THE LABOR MOVEMENT (1928); WERNER SOMBART, WHY IS THERE No SOCLALISM IN AMERICA? (1905); Joel Rogers, Divide and Conquer: Further "Reflections on the Distinctive Character of American Labor Laws", 1990 WIs. L. Rev. 1 (1990).

${ }^{117}$ FORBATH, supra note 1 , at 3.

${ }^{118} \mathrm{Id}$.

${ }^{119} \mathrm{ld}$.

${ }^{20} \mathrm{Id}$.

121 See Pope, supra note 79, at 490 (citing Victoria C. Hattam, Economic Visions and Political Strategies: American Labor and the State, 1865-1896, 4 STUD. AM. POL. Dev. 82, 84 (1990)). 
discuss political action. ${ }^{122}$

Similarly, other critics have noted that Forbath failed to provide sufficient evidence to support his hypothesis that law actually altered Labor's consciousness as opposed to simply changing the strategic weapons employed by Labor. ${ }^{123}$ Indeed, the only "hard" evidence presented by Forbath consists of his citation to four or five internal union communications, ${ }^{124}$ in which unions allegedly "embraced the language" of the judiciary. ${ }^{125}$ This scant evidence hardly supports his broad conclusion that all of Labor adopted and embraced the capitalist system.

Rather than reiterate these criticisms, I shall critique Forbath's underlying message that Labor should abandon its emphasis on collective bargaining and, instead, turn to the political arena where it could seek the broad class-based legislative reform allegedly envisioned by Gilded Age labor activists. Although stating that policy prescriptions are not his stock in trade ${ }^{126}$ Forbath states in his conclusion, that "'rights talk' and 'legal consciousness' sharply delimit the political imaginations of the downtrodden," and that "it seems doubtful that a laissez-faire regime, even a pro-Labor laissezfaire regime, would suffice to meet the aspirations of a great many

122 Pope, supra note 79, at 490 (footnotes omitted); see FINK, supra note 26, at 2325,33 (explaining that the Knights were "ambivalent about the role of the state and the proper political strategy for the labor movement").

${ }^{123}$ Pope, supra note 79, at 490 . Pope argues that Forbath bears the burden of showing "that labor might otherwise have moved in a broader, more political direction." Id.

124 See FoRBATH, supra note 1, at 131-34 (citing Letter from George J. Knott, 28 TYPOGRAPHICAL J. 184, 186 (1906) (referring to a right to persuasion, promising better conditions as being illegal); Letter from George J. Knott, 27 TYPOGRAPHICAL J. 563, 565-66 (1905) (commending rivalry between unions and employers associations as good business); $A$ Just Court Decision, 15 AM. FEDERATIONIST 76 (1908) (commending the reversal of a New York appellate decision granting injunction against strike); Samuel Gompers, Judge Holdom's Injunction Frenzy, 13 AM. FEDERATIONIST 156, 157 (1906) (quoting Indiana Supreme Court's support of the right to peaceful argument and persuasion); Samuel Gompers, Judicial Vindication of Labor's Claims, 7 AM. FEDERATIONIST 283, 284 (1901).

${ }^{125}$ FORBATH, supra note 1, at 132.

${ }^{125} \mathrm{Id}$. at 172. 


\section{NYLS JOURNAL OF HUMAN RIGHTS [Vol. XI}

American workers. "127 Thus, even though he denies that his book contains a political message, Forbath clearly believes that Labor must adopt a broad-based political strategy if Labor intends to survive. ${ }^{128}$ I strongly disagree with this aspect of Forbath's analysis.

In his zeal to demonstrate that the courts played a dominant and motivating role in Labor's decision to abandon legislative reform in favor of private action, ${ }^{129}$ Forbath mistakenly assumes that the American working class has suffered as a result. ${ }^{130}$ Contrary to Forbath's assumption, one can argue persuasively that the American working class has, and will continue to fare better under voluntarism. Indeed, labor economists have repeatedly emphasized that unionized workers in the United States are among the most highly compensated workers in the world. ${ }^{131}$ They receive approximately twenty to twenty-five percent higher pay than their non-union American colleagues, ${ }^{132}$ and they receive substantially greater relative year-toyear salary increases than their European counterparts. ${ }^{133}$ America's trade unionists enjoy "unequalled safeguards against arbitrary treatment," including discharge and layoff, ${ }^{134}$ and a constantly growing list of fringe benefits such as pensions, insurance, and medical benefits. ${ }^{135}$ Finally, unions in America have received substantial credit for reducing the disparity in treatment of African-

in Id.

${ }^{128}$ See id. (expressing doubt that "laissez-faire regime" suffices to meet aspirations of American workers); see also id. at 1 (describing success elsewhere through the use of class-based political movements).

${ }^{129}$ Id. at 8.

${ }^{130}$ FORBATH, supra note 1, at 174.

131 Cf. RICHARD B. FREEMAN \& JAMES L. MEDOFF, WHAT DO UNIONS Do? 46-54 (1983); RONALD G. EHRENBERG \& R. SMTTH, MODERN LABOR ECONOMICS 356-58 (1982).

132 See FREEMAN \& MEDOFF, supra note 131, at 85-86 (comparing hourly pay of blue collar union workers with that of non-union workers, both in the manufacturing sector and non-manufacturing sector).

${ }^{133}$ EHRENBERo \& SMITH, supra note 131, at 358. Between 1971 and 1981, the union/non-union wage differential in America increased by approximately nine percent. Id. at 53. The comparable figure for German workers over a longer time period is approximately $6.2 \%$. Id.

134 Bok, supra note 6, at 1459.

${ }^{135}$ See FREEMAN \& MEDOFF, supra note 131, at 61-77. 
Americans and other minorities. ${ }^{136}$

The American Labor movement's flaw does not lie in the treatment of unionized workers. Rather, its major flaw constitutes the inability of unions to successfully organize large segments of the American population. "The National Labor Relations Act excludes up to fifty percent of the labor force from its coverage . . . ."137 Moreover, among the covered population, the percentage of employees covered by collective bargaining agreements has steadily declined for the past four decades. ${ }^{138}$ In early 1956 , nearly thirtyfour percent of all private nonagricultural workers belonged to labor unions. ${ }^{139}$ By 1980 , that figure had declined to an unprecedented twenty-four percent, ${ }^{140}$ and the latest figures estimate that a mere twelve percent of private sector workers enjoy the benefits of unionism today. ${ }^{141}$

The question Forbath seeks to answer is whether the European system, which affords slightly less protection to a far greater number of persons, is superior to the American system, which affords somewhat greater protection to a far fewer number of persons. Assuming that the European system could be transplanted to America, Forbath argues for the former. ${ }^{142}$ My disagreement does not exist on the ideological level. If I believed that the European system would work in America, I, like most other pro-union Americans, would argue for Labor to place increased emphasis on broad class-based legislative reform. Rather, I disagree with Forbath because I believe that two substantial and insurmountable obstacles exist to the successful adoption of the European-style Labor movement.

136 See, e.g., EHRENBERG \& SMITH, supra note 131, at 356 ("[T]n spite of well publicized conflicts between some unions and civil rights organizations over union seniority rules and the use of racial quotas, unions appear to have improved the economic well-being of black males relative to white males."); FREEMAN \& MEDOFF, supra note 131, at 48-52 (explaining that the rise in union wages between blacks and whites is generally equal).

${ }^{137}$ Bok, supra note 6, at 1418 (footnote omitted).

${ }^{138}$ Id.

${ }^{139}$ FREEMAN \& MEDOFF, supra note 131, at 221.

${ }^{140} \mathrm{ld}$.

${ }^{141}$ Richard Freeman \& Joel Rogers, A New Deal for Labor, N.Y. TIMES, Mar. 10, 1993, at A19.

${ }^{142}$ FORBATH, supra note 1 , at 3. 
First, even if Labor successfully encouraged Congress to enact progressive social legislation, there is no guarantee and, in fact, substantial reason to doubt that today's courts would treat such legislation more favorably than they have treated Labor's latenineteenth century social legislation. Today's federal courts, like the late-nineteenth century courts, have shown outright hostility towards labor and civil rights legislation. In the past decade, the federal courts have restricted the rights of union organizers to speak with non-union employees, ${ }^{143}$ expanded the scope of permissible discrimination against strikers, ${ }^{144}$ limited employees' rights under the Railway Labor Act ${ }^{145}$ to bargain over the very existence of their continued employment, ${ }^{146}$ and upheld the discharge of a union employee for merely attending a rally that urged the boycott of the employer's product. ${ }^{147}$

Similarly, the federal courts have gutted other progressive social legislation over the past decade. In 1989, alone, the Supreme Court issued five decisions interpreting Title VII of the Civil Rights Act of $1964^{148}$ and Section 1981 of the Civil Rights Act of $1870^{149}$ to

${ }^{143}$ See, e.g., Lechmere, Inc. v. NLRB, 112 S. Ct. 841 (1992); see also Peter D. DeChiara, No Solicitation Allowed: Union Organizer Access After Lechmere, Inc., 43 LAB. L.J. 593 (1992) (arguing that "the [NLRB] and the courts took the wrong approach in organizer access cases" and that Lechmere made the situation worse).

144 See, e.g., Trans World Airlines, Inc. v. Independent Fed'n of Flight Attendants, 489 U.S. 426, 443 (1989) (upholding crossover policy providing preferential job placement to non-strikers); Air Line Pilots Ass'n, Int'l. v. United Air Lines, Inc., 802 F.2d 886, 909 (7th Cir. 1986), cert. denied, 480 U.S. 946 (1987) (upholding "superpay" to strike replacements).

145 45 U.S.C. $\$ \S 151-63,181-88$ (1988).

146 See Pittsburgh \& Lake Erie R.R. v. Railway Labor Execs. Ass'n, 491 U.S. 490, 509 (1989) (vacating injunction prohibiting rail carrier from selling assets to non-union subsidiary and firing 500 employees in connection with reorganization); see also Air Line Pilots Ass'n, Int'l. v. Eastern Air Lines, Inc., 863 F.2d 891, 893-94 (D.C. Cir. 1988), cert. dismissed, 112 S. Ct. 37 (1991), and cert. dismissed, 113 S. Ct. 2437 (1993) (vacating injunction prohibiting furlough of 3,388 employees absent exhaustion of the Railway Labor Act's mandatory collective bargaining process).

${ }^{147}$ Hormel Inc. v. NLRB, 962 F.2d 1061, 1066 (D.C. Cir. 1992). An employee's discharge was upheld even though union member "did not address the crowd nor, . . . did he carry a sign, wear a button, or otherwise express in words his support for the boycott." Id.

14842 U.S.C. $\$ 2000 \mathrm{e}-2$ (a) (1988).

14942 U.S.C. $\$ 1981$ (1988). 
significantly dilute important protections against employment discrimination. ${ }^{150}$ In Wards Cove Packing Co. v. Atonio, ${ }^{151}$ for example, the Supreme Court altered the burden of proof in "disparate impact" cases; ${ }^{152}$ thus, the Court placed a significant hurdle in the path of employees who seek to demonstrate that their employer has adopted and implemented a discriminatory employment practice.

Moreover, there is no reason to believe that any new social legislation will receive substantially different treatment. To the contrary, early indications with respect to the Civil Rights Act of $1991^{153}$ (1991 Act) indicate that the conservative federal judges, appointed by former Presidents Reagan and Bush, will continue to disembowel any progressive legislation. ${ }^{154}$ Notwithstanding the stated goal of the 1991 Act, ${ }^{155}$ the federal courts' first experiences with it

${ }^{150}$ See, e.g., Wards Cove Packing Co. v. Atonio, 490 U.S. 642, 645-46 (1989) (defining unfair employment practices under Title VII of the Civil Rights Act of 1964 as determined by "disparate-impact" theory construed in Griggs v. Duke Power Co., 401 U.S. 424, 431 (1971)); Patterson v. McLean Credit Union, 491 U.S. 164, 171 (1989) (considering the fact that the Civil Rights Act of 1870 does not apply to conduct occurring "after the formation of a contract and which does not interfere with the right to enforce established contract obligations."); Martin v. Wilks, 490 U.S. 755, 758-59 (1989) (holding that white fire-fighters in Birmingham, Alabama, were deprived of their legal rights, despite the fact that they were not parties to consent decree proceedings); Price Waterhouse v. Hopkins, 490 U.S. 228 (1989) (altering the burden of proof under Title VII by interpreting congressional intent); Lorance v. AT\&T Technologies, Inc., 490 U.S. 900, 903-04 (1989) (interpreting the "limitations period" as defined under Title VII).

151490 U.S. 642 (1989).

${ }^{152}$ Id. at 659-60 (finding that the standard of review, "that the challenged practice be 'essential' or 'indispensable' to the employer's business," is all but impossible for employers to meet).

${ }^{153}$ Pub. L. No. 102-166, 105 Stat 1071 (1991).

154 See J.R. Franke, The Civil Rights of 1991: Remedial Civil Rights Policies Prevail, 17 S. ILl. U. L.J. 267, 296-97; see, e.g., Majer v. Metropolitan Transp. Auth., No. 90 Civ. 4608, 1992 WL 110995, at *1, *3 (S.D.N.Y. May 7, 1992) (barring the application of the 1991 Act because "Labor Law Sect. 740 is analogous to prior version of Title VII").

${ }^{15 S}$ H.R. Rep. No. 102-40(I), 102d Cong., 1st Sess. (1991), reprinted in 1991 U.S.C.C.A.N. 549, 552. The stated goal of the 1991 Act is twofold: First, to provide monetary remedies for victims of intentional employment discrimination to compensate them for resulting injuries and to provide more effective deterrence; and second, to respond to the United States Supreme Court's recent decisions by restoring federal civil rights protections against employment discrimination. Id. Compare with holdings of 


\section{NYLS JOURNAL OF HUMAN RIGHTS [Vol. XI}

resulted in holdings that the 1991 Act would not apply retroactively. ${ }^{156}$

Second, even if social legislation survived judicial scrutiny, employer resistance would likely render social reform meaningless for most Americans. Forbath would likely agree that throughout the course of labor relations in America, employers and employerorganizations have made strong and persistent efforts to avoid unions, collective bargaining, and other forms of worker protection. ${ }^{157}$ As Professor Bok has articulated:

[E]ven a cursory study of the cases brought before the NLRB reveals the extent of determined opposition to collective bargaining that still persists. Thousands of cases are brought each year alleging the firing of employees for engaging in union activities, and the number of these complaints is constantly growing. ${ }^{158}$

Susan Catler mentions that the extension of "union-like" rights to non-union employees would in the long run harm American workers by providing them with a false sense of security. ${ }^{159}$ For instance, Catler argues that most judicial or legislative actions to abolish the employment "at will". doctrine would be both

cases cited supra note 150.

${ }^{156}$ See Vogel v. City of Cincinnati, 959 F.2d 594, 598 (6th Cir. 1992) (holding that the 1991 Act did not apply retroactively and that a hiring policy adopted by consent decree was subject to the law in effect at that time); Fray v. Omaha World Herald Co., 960 F.2d 1370, 1378 (8th Cir. 1992) (concluding that \& 101 of the 1991 Act, which overruled Patterson v. McClean Credit Union, 491 U.S. 164 (1989), "should not be retroactively applied to pending cases or other pre-enactment conduct"); Mozee v. American Commercial Marine Serv. Co., 963 F.2d 929, 932 (7th Cir. 1992) (holding "that provisions of the 1991 Act apply prospectively on appeal"); Luddington v. Indiana Bell Tel. Co., 966 F.2d 225, 229 (7th Cir. 1992) (holding that the 1991 Act "is applicable only to conduct engaged in after the effective dates"); Johnson v. Uncle Ben's Inc., 965 F.2d 1363, 1372 (5th Cir. 1992) (following holdings of Sixth, Seventh, and Eighth Circuits).

${ }^{157}$ Bok, supra note 6, at 1410.

158 Id. (footnote omitted).

${ }^{159}$ Susan L. Catler, The Case Against Proposals to Eliminate the Employment at Will Rule, 5 INDUS. REL. L.J. 471, 472 (1983). 
inappropriate and ineffective for two reasons. ${ }^{160}$

Catler's first reason is that a lawsuit "is substantially more complex, legalistic and costly than filing a union grievance and, thus, less accessible to employees. "161 Catler's observation is borne out by a review of wrongful discharge cases brought under state law. ${ }^{162}$ Even a scant review of such decisions demonstrates the vast majority of cases are brought by highly compensated white-collar employees. ${ }^{163}$ Second, Catler asserts that statutorily mandated reinstatement schemes, outside the collective bargaining context, tend to provide an inadequate remedy for unjust dismissal. ${ }^{164}$ Putting one and two together, Catler concludes that government legislation may actually harm American workers:

Theoretically, granting a right not to be discharged without just cause might actually weaken the position of currently unprotected individuals. This would occur if, as a result of the statutory provision, employees voted not to unionize because the marginal value of a union contract was not sufficiently attractive to support an organizing drive .... [T]he position of some at will employees would also be weakened if, as a result of the statutory provision, workers who would otherwise have sought jobs in unionized shops or positions covered by civil service legislation took jobs protected only by the statute. ${ }^{165}$

Agreeing with the aforementioned scholars, I find that I cannot embrace Forbath's argument that Labor should abandon collective bargaining and, instead, seek broad class-based social reform. I do, however, embrace Forbath's sub-theme that Labor should engage in nonviolent civil disobedience. ${ }^{166}$

\footnotetext{
${ }^{160} \mathrm{Id}$. at 471.

${ }^{161}$ Id. at 496 (footnotes omitted).

162 Id. at $496-97$.

${ }^{163} \mathrm{Id}$.

${ }^{164}$ Catler, supra note 159, at 505-06.

${ }^{165}$ Id. at 507; see Bok, supra note 6, at 1439.

${ }^{166}$ See FORBATH, supra note 1, at 8, 173.
} 


\section{NYLS JOURNAL OF HUMAN RIGHTS [Vol. XI}

Although not appropriately emphasized by Forbath, his brief account of Labor's organized defiance of injunctions and court orders demonstrates that Labor achieved its greatest gains, both at the bargaining table and in Washington, when it openly defied those "unjust" laws that treated Labor and Capital differently. ${ }^{167}$ As other critics have noted, this argument has already won support from a growing body of scholars who have emphasized the essential role of disruption in winning labor law reform. ${ }^{168}$ For example, Professor James Atelson's comparative study of American and Canadian reform efforts concludes that the Canadian Labor movement has been more successful than the American Labor movement in organizing workers, largely because of Canada's greater militancy. ${ }^{169}$ Similarly, Alan Hyde and Michael Goldfarb have concluded that sharp increases in worker unrest are usually followed by labor law reform. ${ }^{170}$ Moreover, America's experience with Civil Rights movement in the 1960s further confirms that the most effective way to overcome "unjust" laws is through civil disobedience. ${ }^{171}$

Unfortunately, Forbath quickly passes over this important chapter in the American Labor movement. Forbath over-romanticizes the Knights of Labor's broad social vision and argues for the impossible, rather than examining the potential for similar class-based civil disobedience today.

\section{Conclusion}

Forbath's Law and the Shaping of the American Labor

${ }^{167}$ Id. at $142-47$.

${ }^{168}$ See Pope, supra note 79, at 488-89.

${ }^{169}$ Id. at 499 (citing James Atelson, The Prospects for Labor Law Reform, 18 POL'Y STUD. J. 364 (1989-90)).

170 Alan Hyde, A Theory of Labor Legislation, 38 BUFF. L. REV. 383, 445-46 (1990); Michael Goldfarb, Worker Insurgency, Radical Organization, and New Deal Legislation, 83 AM. POL. SCI. REV. 1257, 1270-73 (1989).

${ }^{171}$ Bruce Ledewitz, Civil Disobedience, Injunctions, and the First Amendment, 19 HOPSTRA L. REv. 67, 76-82 (1990) (discussing certain movements during the 1960s, including protests against the Vietnam War consisting of sit-ins and road blocks, and Dr. Martin Luther King's address in 1968, calling for "mass civil disobedience" that would cause societal interruption, in order to dramatize racism, poverty, and unemployment). 
Movement adds an important piece of scholarship to what was becoming an increasingly stale debate regarding the distinctiveness of the American Labor movement. His book provides a long needed alternative explanation for the "uniqueness" of the American Labor movement. Although Forbath has fully researched the effect that law has had on the American Labor movement, he mistakenly glosses over the most successful chapter in American labor history and argues for a return to the social policies which have already proven unworkable. Rather than learn from the past, Forbath seeks to repeat it. His brilliant historical account, however, largely makes up for this normative folly. 
